\title{
Oxidation of Nickel in AlCl3-1- Butylpyridinium Chloride at Ambient Temperature
}

$\operatorname{AUTHOR}(\mathrm{S})$ :

Nakaya, K.; Nakata, A.; Hirai, T.; Ogumi, Z.

\section{CITATION:}

Nakaya, K.... [et al]. Oxidation of Nickel in AlCl3-1-Butylpyridinium Chloride at Ambient Temperature. Journal of the Electrochemical Society 2014, 162(1): D42-D48

\section{ISSUE DATE:}

2014-11-13

URL:

http://hdl.handle.net/2433/196780

\section{RIGHT:}

(c) The Author(s) 2014. Published by ECS.; This is an open access article distributed under the terms of the Creative Commons Attribution 4.0 License (CC BY, http://creativecommons.org/licenses/by/4.0/), which permits unrestricted reuse of the work in any medium, provided the original work is properly cited. 


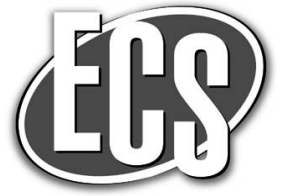

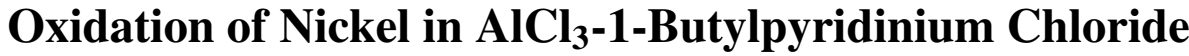 at Ambient Temperature
}

\author{
Katsunori Nakaya,, ${ }^{\mathrm{a}, \mathrm{z}}$ Akiyoshi Nakata, Toshiro Hirai, ${ }^{*}$ and Zempachi Ogumi** \\ Office of Society-Academia Collaboration for Innovation, Kyoto University, Uji-shi, Kyoto 611-0011, Japan
}

\begin{abstract}
We have studied in detail the electrochemical reaction of nickel in several kinds of molar ratio-controlled molten salts consisting of $\mathrm{AlCl}_{3}$ and 1-butylpyridinium chloride (BPC) at $40^{\circ} \mathrm{C}$. We observed $\mathrm{NiCl}_{2}$ as an oxidation product from nickel on the surface of the electrode in slightly acidic $\mathrm{AlCl}_{3} / \mathrm{BPC}$ salts with molar ratios of $1.05 / 1.0$ and 1.1/1.0. However, in strongly acidic salt with the ratio of 1.5/1.0, $\mathrm{NiCl}_{2}$ deposits on the electrode less than when in the above salts, and no $\mathrm{NiCl}_{2}$ is observed in basic and neutral salts with the ratio of 1.0/1.0 or less $\mathrm{AlCl}_{3}$ content. This suggests that $\left[\mathrm{NiCl}_{4}\right]^{2-}$ ions form as the oxidation of nickel in such neutral and basic $\mathrm{AlCl}_{3} / \mathrm{BPC}$ salts.

(C) The Author(s) 2014. Published by ECS. This is an open access article distributed under the terms of the Creative Commons Attribution 4.0 License (CC BY, http://creativecommons.org/licenses/by/4.0/), which permits unrestricted reuse of the work in any medium, provided the original work is properly cited. [DOI: 10.1149/2.0401501 jes] All rights reserved.
\end{abstract}

Manuscript submitted September 19, 2014; revised manuscript received October 30, 2014. Published November 13, 2014.

Lithium-ion batteries are the most appealing power sources that operate at a higher voltage and achieve a higher energy density, compared with nickel metal-hydride batteries, and are now widely used in commercial hybrid electric vehicles. ${ }^{1,2}$ Lithium-ion batteries, however, are not competitive with gasoline engines to date because of their limited energy density. Therefore, intensive efforts have been done to develop new rechargeable batteries with far higher energy density than the present lithium-ion batteries. ${ }^{3-8}$ One effective approach to developing batteries with high energy density is to find a new type of cell systems that is charged and discharged accompanied by multiple-ions transport.

Nickel compounds have been expected to be one of the cathode active materials for high energy batteries. Nickel oxyhydroxide, for example, has been used as a cathode active material for commercial nickel-cadmium and nickel-metal hydride batteries ${ }^{9}$ and also investigated as cathode active materials for other high energy batteries such as zinc-nickel batteries. ${ }^{10,11}$ Nickel compounds are also expected to be cathode active materials for high energy batteries having nonaqueous electrolytes. Lithium nickel oxides and their derivatives have also been expected to be cathode active materials for high energy density lithium-ion batteries. ${ }^{1}$

Batteries having $\mathrm{Al}$ anode and molten salt have been studied as one appealing alternative. Some battery systems have been expected to operate by the reaction for plural chloride ion transfer. Knutz et al. operated a battery containing nickel cathode and inorganic molten salts consisting of $\mathrm{AlCl}_{3}$ and $\mathrm{NaCl}$ at $175^{\circ} \mathrm{C}$ and studied its electrochemical properties. ${ }^{12,13}$ Gilbert et al. investigated the electrochemical properties of nickel in molten salts consisting of $\mathrm{AlCl}_{3}$ and $\mathrm{KCl}$ at $175-210^{\circ} \mathrm{C}^{14}$

On the other hand, electrochemical properties for molten salts containing $\mathrm{AlCl}_{3}$ and organic salts have also been widely studied. ${ }^{15-29}$ Such chloroaluminate salts vary their melting points, decreasing to lower temperature as they approach, by changing the ratio of $\mathrm{AlCl}_{3}$ and organic salts, although their ion conductivity has been reported to be well maintained. Accordingly, many studies have been done on electrochemical properties for chloroaluminate salts with organic salts at around $100^{\circ} \mathrm{C}$ or ambient temperature in view of application for batteries as well as electro-deposition of metals and sensors. Koura et al. studied electrochemical properties of $\mathrm{Al} / \mathrm{FeS}_{2}$ and $\mathrm{Al} /$ polyaniline batteries containing $\mathrm{AlCl}_{3}$ - $\mathrm{BPC}$ or $\mathrm{AlCl}_{3}$-1-ethyl-3-methylimidazolium chloride (EMIC) at ambient temperature or $100^{\circ} \mathrm{C}^{17-20}$ They attempted to improve the cell performance by adopting alloy anode, ${ }^{17}$ additives for molten salts. ${ }^{18-20}$ Donahue et al. estimated charge and

\footnotetext{
*Electrochemical Society Active Member.

**Electrochemical Society Fellow.

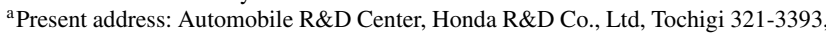
Japan.

zE-mail: Katsunori_Nakaya@n.t.rd.honda.co.jp
}

discharge performance of $\mathrm{Al} / \mathrm{FeCl}_{3}$ batteries containing $\mathrm{AlCl}_{3}$-EMIC at ambient temperature. ${ }^{22}$

A cell system having $\mathrm{Al}$ anode and $\mathrm{NiCl}_{2}$ cathode is reported to respectively show $301.5 \mathrm{Wh} \mathrm{kg}^{-1}$ and $1021.1 \mathrm{Wh}^{-1}$ of theoretical gravimetric and volumetric energy density based on $0.83 \mathrm{~V}$ of ideal cell voltage..$^{30}$ Nickel chloride has been anticipated to be a good cathode active material for high energy batteries with non-aqueous electrolyte in cooperation with $\mathrm{Al}$ anode and chloroaluminate as electrolyte.

The electrochemical properties of nickel/nickel chloride have therefore been investigated as an interesting cathode active material in cooperation with $\mathrm{Al}$ anode and chloroaluminate salts with organic salts. Osteryoung et al. investigated the electrochemical properties of $\mathrm{NiCl}_{2}$ with cyclic voltammetry in acidic and basic salts of $\mathrm{NiCl}_{2}$ dissolved in $\mathrm{AlCl}_{3}$-BPC at room temperature, $40^{\circ} \mathrm{C}$, and $150^{\circ} \mathrm{C}$, and estimated an equilibrium constant for the reaction of $\left[\mathrm{NiCl}_{4}\right]^{2-} \mathrm{Ni}^{2+}$ $+4 \mathrm{Cl}^{-} \cdot{ }^{16}$ However, they did not analyze the products deposited on the electrode. O'Grady et al. also intensively investigated the electrochemical properties of $\mathrm{NiCl}_{2}$ with cyclic voltammetry and other metals that were first dissolved in $\mathrm{AlCl}_{3}$-EMIC and then deposited on to the Pt plate at room temperature. ${ }^{23-26}$ They analyzed the electrolyte after oxidizing nickel but did not identify the product of $\mathrm{NiCl}_{2}$ on the Pt electrode. ${ }^{23}$ Kohl et al. also studied some metals behavior in the $\mathrm{NaCl}$-buffered $\mathrm{AlCl}_{3}$-EMIC salt. They investigated the formation of $\mathrm{NiCl}_{2}$ on the surface of nickel wire electrode but did not perform the chemical analysis of the product. ${ }^{27}$ Considering these studies, a cell system having $\mathrm{Ni}$ cathode, $\mathrm{Al}$ anode, and chloroaluminate salts containing organic salts is expected to be an attractive rechargeable battery that can operate at ambient temperature. On the other hand, the electrochemical reaction may be strongly affected by the molar ratio of the $\mathrm{AlCl}_{3}$ and organic salts. Few reports, however, have been published on the detailed results on electrochemical properties such as cyclic voltammograms depending on the molar ratio of $\mathrm{AlCl}_{3}$ /organic salt. ${ }^{23,26}$ Furthermore, few studies on oxidation of $\mathrm{Ni}$ have been reported in spite of several studies on reduction of $\mathrm{NiCl}_{2} \cdot{ }^{23}$ Specifically, no reports relate any identified products deposited on the electrode by oxidizing Ni. The confirmation and identification of deposited products of nickel and nickel chloride after charging and discharging are very important to establish a practical $\mathrm{Ni}$ cathode for $\mathrm{Al} / \mathrm{Ni}$ rechargeable cells.

It is also important to find an optimum Lewis acidity of $\mathrm{AlCl}_{3}$ /organic salt to establish and repeat effective oxidation of nickel and reduction of nickel chloride because such reactions need supply and regeneration of chloride ions. We thus have studied oxidation of nickel to nickel chloride in detail in the molten salts consisting of $\mathrm{AlCl}_{3}$ and $\mathrm{BPC}$ in view of the influence of the properties on the molar ratio of the molten salts, especially in detailed acidic ones, to relate to the reversibility of the $\mathrm{Ni}$ electrode. We have made a significant point of confirming the product deposited on the electrode 
after oxidizing nickel and identifying the deposition as nickel chloride.

\section{Experimental}

Electrolytes and electrodes were prepared under inert gas and dry condition $\left(\mathrm{O}_{2}\right.$ content less than $3 \mathrm{ppm}$ and dew point less than $\left.-80^{\circ} \mathrm{C}\right)$ inside an Ar-filled globe box.

Electrolytes. - Aluminum chloride (99.8\%, Wako Pure Chemical Industries) and 1-butylpyridinium chloride (98\%, Tokyo Chemical Industry) were dried under vacuum at $75^{\circ} \mathrm{C}$ for $72 \mathrm{~h}$. The electrolytes containing $\mathrm{AlCl}_{3}$ and BPC with molar ratios of 0.8/1.0, 0.9/1.0, $1.0 / 1.0,1.05 / 1.0,1.1 / 1.0$ and $1.5 / 1.0$ were prepared by stirring in Teflon vessels to avoid generating heat. The electrolytes were dehydrated by immersion with polished $\mathrm{Al}$ wire $(99.999 \%$ and $1.0 \mathrm{~mm}$ diameter, Nilaco) for two weeks or longer and we checked the purity of eletrolytes by cyclic voltammetry using Pt electrode between $0.2 \mathrm{~V}$ and $1.8 \mathrm{~V}$ at a scan rate of $1.0 \mathrm{mVs}^{-1}$. No peaks of electrochemical reaction related to impunity were observed in the CV.

Electrodes.-Nickel electrode A.- $0.1 \mathrm{~mm}$ thick nickel plate $(99 \%$, Nilaco) was cut into pieces $5 \mathrm{~mm}$ wide and $10 \mathrm{~mm}$ long and welded to $\mathrm{Ni}$ wire $(99.9 \%$ and $1.0 \mathrm{~mm}$ diameter, Nilaco) onto the plate to use as working electrodes. The surface of the electrodes was polished thoroughly before electrochemical measurements.

Nickel electrode B.-We used Ni powder (99.8\%, Aldrich) and poly vinylidene fluoride (PVDF, HSV900, Arkema). Before use, Ni and PVDF powder was dried at $120^{\circ} \mathrm{C}$ in a vacuum for 16 hours. We made PVDF $6 \mathrm{wt} \%$ solution with N-methyl-2-pyrroridone dehydrated below 20 ppm (NMP, Kishida Chemical) previously and added Ni powder to the solution to be consistent with the weight ratio of $\mathrm{Ni}: \mathrm{PVDF}=9$ : 1 and slurried. We coated this slurry onto Pt mesh $(99.98 \%, 80 \mathrm{mesh}$, Nilaco). The sheet was roll-pressed and cut after drying in a vacuum at $80^{\circ} \mathrm{C}$ overnight. We then welded $1.0 \mathrm{~mm}$-diameter $\mathrm{Ni}$ wire to the cut $\mathrm{Ni}$ composite sheet to use as a positive electrode.

Al electrode A.-Counter and reference electrodes were prepared by polishing and coiling Al wire (99.999\% and $1.0 \mathrm{~mm}$ diameter, Nilaco) of $2 \mathrm{~mm}$ diameter and $10 \mathrm{~mm}$ long.

Al electrode B.-As a negative electrode, $0.1 \mathrm{~mm}$ thick Al plate (99.999\%, Nilaco) was cut into pieces $5 \mathrm{~mm}$ wide and $30 \mathrm{~mm}$ long. The surface of the electrodes was polished thoroughly before the experiment.

Pt electrode. - Pt wire (99.95\% and $0.5 \mathrm{~mm}$ diameter, EC Frontier) was coiled in $2.5 \mathrm{~mm}$ diameter and $15 \mathrm{~mm}$ long and used as a working electrode for CVs to check existence of impurity in the molten salts, as described above.

Solubility of $\mathrm{NiCl}_{2}$ into $\mathrm{AlCl}_{3} / \mathrm{BPC}$ electrolytes. - We roughly estimated the $\mathrm{NiCl}_{2}$ solubility into $\mathrm{AlCl}_{3} / \mathrm{BPC}$ salts with $\mathrm{AlCl}_{3} / \mathrm{BPC}$ molar ratios of $0.9 / 1.0,1.0 / 1.0$, and $1.5 / 1.0$. We added $2.6 \mathrm{mg}(0.001$ mol $1^{-1}$ ) each of $\mathrm{NiCl}_{2}$ powder into $20 \mathrm{ml}$ of the electrolyte at $35^{\circ} \mathrm{C}$, followed by stirring for over 20 hours for the 1.0/1.0 and 1.5/1.0 ratio salts. For the $0.9 / 1.0$ ratio salt, we first dissolved $26 \mathrm{mg}\left(0.01 \mathrm{~mol} \mathrm{l}^{-1}\right)$ into $20 \mathrm{ml}$ of the salt stirring for over 20 hours, followed by adding 2.6 $\mathrm{mg}$ each by the same procedure as described above. We then stopped stirring to let the solution stand for over 3 hours, and visually checked the turbidity of the solution and precipitation. When no turbidity and no precipitation were observed, we again added $2.6 \mathrm{mg}$ of the $\mathrm{NiCl}_{2}$ powder and repeated the procedure until turbidity or precipitation was observed. We here defined the solubility of $\mathrm{NiCl}_{2}$ as an integer of $0.001 \mathrm{~mol} \mathrm{l}^{-1}$.

Electrochemical measurements.- Working, counter, and reference electrodes were set and the electrolyte was poured into an inverted conical glass vessel and sealed to form a test cell. Test cells were placed on a heated plate to keep the temperature at $40^{\circ} \mathrm{C}$ into the argon-filled globe box for cyclic voltammetry and other electrochemical measurements. CELL TEST-2 (Solartron) and potentio/galvanostat SP-200 (Bio-Logic) were used for the measurements.

Surface analysis of the electrodes. - Test electrodes were washed twice with acetonitrile dehydrated below $10 \mathrm{ppm}$ (Kishida Chemical) and dried. The samples were offered with no exposure to air for analyses. XRD spectra of the surface of the electrodes were obtained by a D8 ADVANCE (BRUKER). The surface condition of the electrode was observed with a scanning electron microscope SU6600 (Hitachi). The product on the electrodes was identified with an X-ray photoelectron spectroscopy PHI Quantetra SXM (ULVAC-PHI). Etching depth of nickel electrode was referred to the etching rate of $\mathrm{SiO}_{2}$ standard thin film.

\section{Results and Discussion}

One of the most significant issues for metal chloride electrodes is excessive dissolution in electrolytes, and the solubility critically depends on basicity of the salt electrolytes. We therefore broadly investigated the dependency of $\mathrm{NiCl}_{2}$ solubility on the $\mathrm{AlCl}_{3} / \mathrm{BPC}$ electrolytes. The solubility increased with a decrease in the $\mathrm{AlCl}_{3} / \mathrm{BPC}$ ratio: $0.001 \mathrm{~mol} \mathrm{l}^{-1}$ for the $1.5 / 1.0$ salt, $0.003 \mathrm{~mol} \mathrm{l}^{-1}$ for the $1.0 / 1.0$ salt, and $0.015 \mathrm{~mol} \mathrm{l}^{-1}$ for the $0.9 / 1.0$ salt. The formation of $\left[\mathrm{NiCl}_{4}\right]^{2-}$ ions may dissolve $\mathrm{NiCl}_{2}$ into an electrolyte with a smaller ratio of $\mathrm{AlCl}_{3} / \mathrm{BPC},{ }^{16}$ as follows:

$$
\mathrm{NiCl}_{2}+2 \mathrm{Cl}^{-} \rightarrow\left[\mathrm{NiCl}_{4}\right]^{2-}
$$

Figure 1 illustrates cyclic voltammograms $(\mathrm{CV})$ for $\mathrm{Ni}$ plate as "Ni electrode $\mathrm{A}$ " in $\mathrm{AlCl}_{3}$ - $\mathrm{BPC}$ with different molar ratios at $40^{\circ} \mathrm{C}$. The rest potential was $0.55 \mathrm{~V}$ vs. $\mathrm{Al} / \mathrm{Al}^{3+}$ for the $0.8 / 1.0$ salt (Fig. 1a), $0.64 \mathrm{~V}$ vs $\mathrm{Al} / \mathrm{Al}^{3+}$ for the $0.9 / 1.0$ salt (Fig. 1 b), and $0.22 \mathrm{~V} \mathrm{vs} \mathrm{Al} / \mathrm{Al}^{3+}$ for the 1.0/1.0 salt (Fig. 1c), respectively. The scanning started in cathodic direction. The behavior in basic and acidic salts is very different because of variations in the nickel complex in the two regions. For the 0.8/1.0 and 0.9/1.0 molar ratio salts (Figs. 1a and 1b). Anodic current peaked at around $1.1-1.2 \mathrm{~V}$ vs. $\mathrm{Al} / \mathrm{Al}^{3+}$, and the peak shifted positively with an increase in $\mathrm{AlCl}_{3}$ ratio and through cycling. Considering the CV results in Ref. ${ }^{23}$ and the fact that the solution turned blue after the measurement, the anodic peak may correspond to a reaction whereby $\mathrm{Ni}$ was oxidized and $\left[\mathrm{NiCl}_{4}\right]^{2-}$ ions produced, as follows:

$$
\mathrm{Ni}+4 \mathrm{Cl}^{-} \rightarrow\left[\mathrm{NiCl}_{4}\right]^{2-}+2 \mathrm{e}^{-}
$$

On the other hand, weak cathodic current peak was observed at around $0.2-0.3 \mathrm{~V}$ vs. $\mathrm{Al} / \mathrm{Al}^{3+}$. The cathodic peak may be due to the reduction of nickel oxides or $\mathrm{Ni}^{2+}$ ions, ${ }^{28,29}$ although it may contain complicated reduced products from nickel complex ions. This suggests that Reaction 2 progressed irreversibly or dominantly in the forward direction to form $\left[\mathrm{NiCl}_{4}\right]^{2-}$ ions.

For neutral-like $\mathrm{AlCl}_{3} / \mathrm{BPC}$ salt with a molar ratio of $1.0 / 1.0, \mathrm{CV}$ profiles are observed to differ from those of the basic salts (Fig. 1c). Prominent anodic peaks appeared at 0.4 and $0.5 \mathrm{~V}$ vs. $\mathrm{Al} / \mathrm{Al}^{3+}$ and the peak at around $1.1 \mathrm{~V}$ disappeared. This is thought to be the main reason why the EMF value of each electrode changed with the change in molar ratio of the $\mathrm{AlCl}_{3} / \mathrm{BPC}$ salt ${ }^{15}$ and the change in EMF varies according to each electrode material. ${ }^{15,16}$ Anodic current in Fig. 1c was smaller than that in Figs. 1a and 1b. It suggests that difference in $\mathrm{Cl}^{-}$ ion concentration in the salts mainly caused the difference in anodic current. ${ }^{15}$ However, other factors as well as $\mathrm{Cl}^{-}$ion concentration may affect to the difference in current, especially in near 1.0/1.0 molar ratio. Further study is needed to clarify it. The weak peak at around $0.15 \mathrm{~V}$ vs. $\mathrm{Al} / \mathrm{Al}^{3+}$ may be attributed to $\mathrm{Ni}$ deposition. ${ }^{28,29}$ In the region of more positive potential than $0.8 \mathrm{~V}$ vs. $\mathrm{Al} / \mathrm{Al}^{3+}$ in Fig. 1c, continuous current was observed through anodic and cathodic sweeps, which suggests that nickel continuously dissolved in the salt and a kind of ionic balance between $\left[\mathrm{NiCl}_{4}\right]^{2-},\left[\mathrm{NiCl}_{3}\right]^{-}, \mathrm{Ni}^{2+}$, and other ions occurred to take the place of weak current peaks. In fact, the solution turned blue after the $\mathrm{CV}$ measurements, which suggests that 

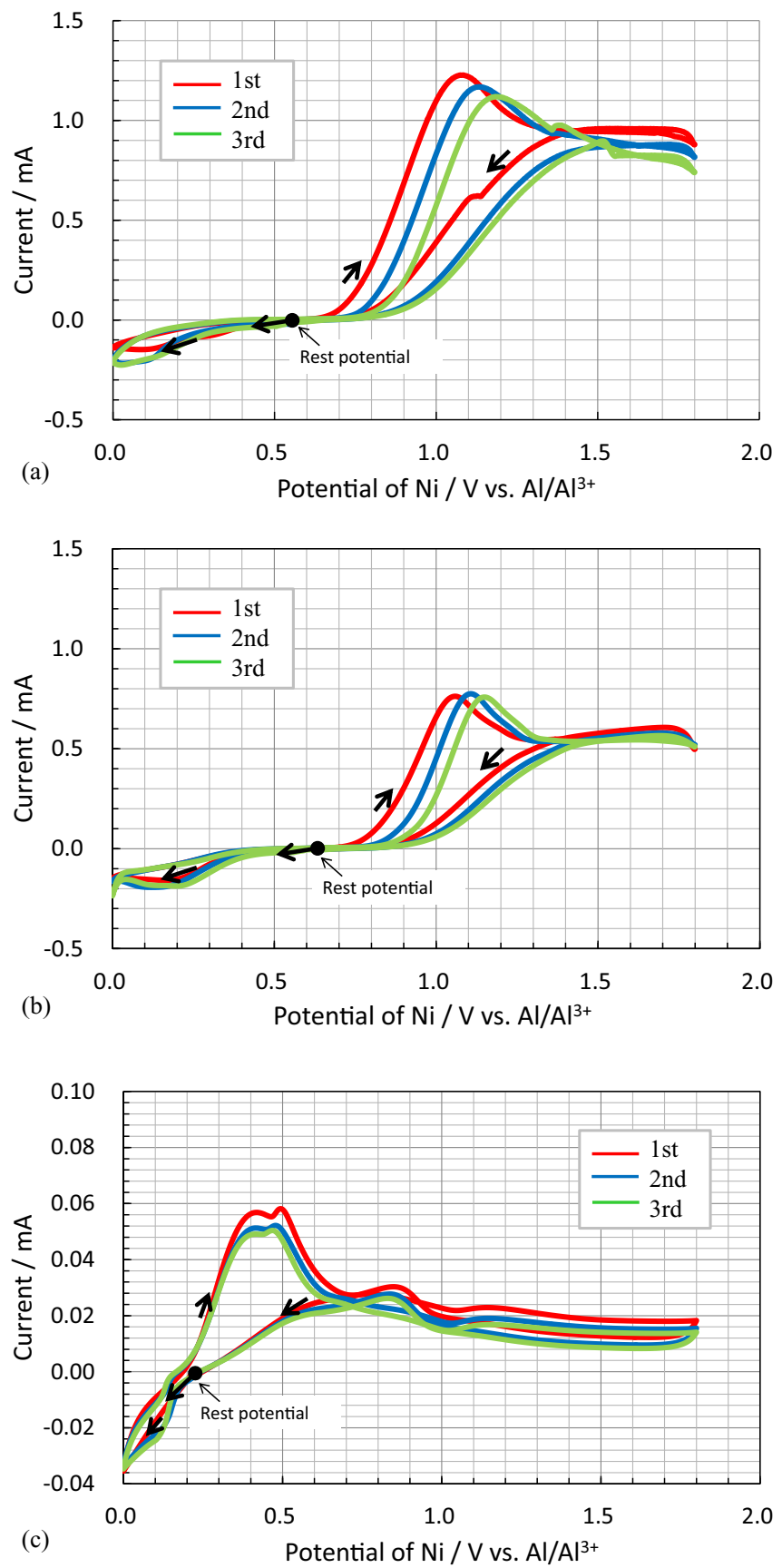

Figure 1. Cyclic voltammograms of $\mathrm{Ni}$ plate for the cell having $\mathrm{Al}$ coil as counter and reference electrodes and the $\mathrm{AlCl}_{3} / \mathrm{BPC}$ molten salt at $40^{\circ} \mathrm{C}$. Scan rate was $1 \mathrm{mV} \mathrm{s}^{-1}$. (a) $\mathrm{AlCl}_{3} / \mathrm{BPC}$ salt with molar ratio of $0.8 / 1.0$. (b) $\mathrm{AlCl}_{3} / \mathrm{BPC}$ salt with molar ratio of $0.9 / 1.0$. (c) $\mathrm{AlCl}_{3} / \mathrm{BPC}$ salt with molar ratio of $1.0 / 1.0$

$\left[\mathrm{NiCl}_{4}\right]^{2-}$ ions formed in the salt and is related to the appearance of the weak current peaks. Further study is needed to clarify this point.

We confirmed $\left[\mathrm{NiCl}_{4}\right]^{2-}$ formation in the salts as follows: we assembled cells containing "Ni electrode B" as positive and "Al electrode B" as negative electrodes set at intervals of $15 \mathrm{~mm}$ into salt with $\mathrm{AlCl}_{3} / \mathrm{BPC}$ molar ratios of $0.8 / 1.0$ and 1.5/1.0. Two cells were placed under an open circuit for 16 hours at $40^{\circ} \mathrm{C}$. The $0.8 / 1.0$ molar ratio salt turned blue, but the 1.5/1.0 molar ratio salt did not change in color. We then washed the Al plate electrodes with acetonitrile in order to subject them to XRD and XPS measurements.

No peaks attributed to nickel were observed in the XRD pattern of the $\mathrm{Al}$ electrode in either of the two salts, as shown in Fig. 2a
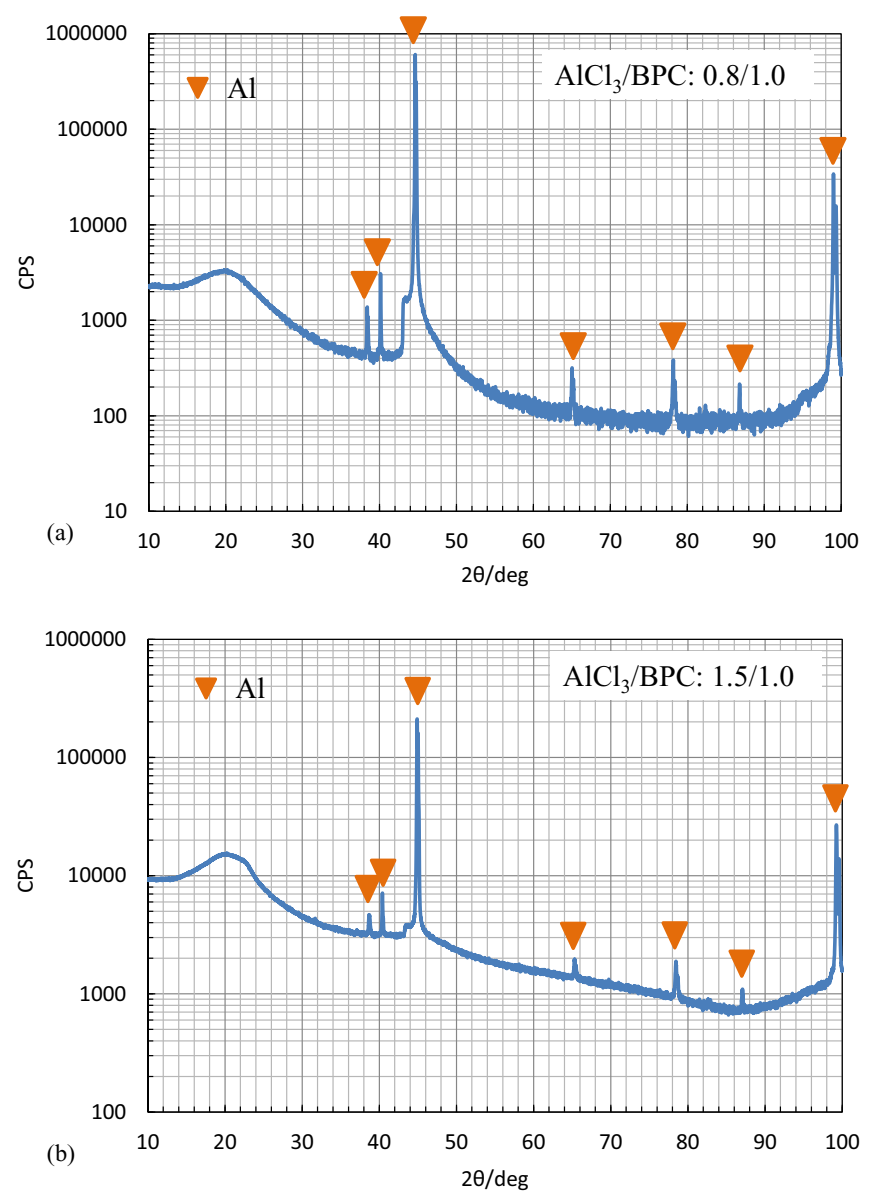

Figure 2. XRD pattern of $\mathrm{Al}$ plate for the cell having $\mathrm{Ni}$ composite as positive, Al plate as negative electrode after standing for $16 \mathrm{hr}$ at $40^{\circ} \mathrm{C}$. (a) In $\mathrm{AlCl}_{3} / \mathrm{BPC}$ salt with molar ratio of $0.8 / 1.0$. (b) $\mathrm{In} \mathrm{AlCl}_{3} / \mathrm{BPC}$ salt with molar ratio of $1.5 / 1.0$.

and Fig. 2b. On the other hand, Ni2p and Al2s XPS spectra indicated differences in the Al plate surfaces between the two salts. Nickel was not deposited, however, aluminum oxide film only existed on the Al surface for the $0.8 / 1.0$ molar ratio salt (Fig. 3a). For the 1.5/1.0 molar ratio salt, however, more than $80 \mathrm{~nm}$-thick $\mathrm{Ni}$ was deposited on the Al surface (Fig. 3b). This suggests that nickel oxides on the surface of nickel particles were dissolved and changed to stable $\left[\mathrm{NiCl}_{4}\right]^{2-}$ ions with excess $\mathrm{Cl}^{-}$ions in the $0.8 / 1.0$ molar ratio salt, ${ }^{15}$ and, in the 1.5/1.0 molar ratio salt, nickel oxides were dissolved and deposited on the $\mathrm{Al}$ surface, replacing $\mathrm{Al}$ dissolution as a local cell reaction on the $\mathrm{Al}$ negative electrodes.

We then performed cyclic voltammetry for the slightly acidic, 1.05/1.0 molar ratio salt on the cell with Ni plate as a working electrode and $\mathrm{Al}$ coil as a counter and a reference. The rest potential was $0.92 \mathrm{~V}$ vs $\mathrm{Al} / \mathrm{Al}^{3+}$ and the $\mathrm{CV}$ was started to scan in the cathodic direction. The result is shown in Fig. 4. A strong anodic peak was observed at $1.17 \mathrm{~V}$ vs. $\mathrm{Al} / \mathrm{Al}^{3+}$ in the first sweep and weakly broad cathodic peaks were observed at around 0.5 and $0.2 \mathrm{~V}$ vs. $\mathrm{Al} / \mathrm{Al}^{3+}$ in the second and later sweeps. The peak at $1.17 \mathrm{~V} \mathrm{vs.} \mathrm{Al} / \mathrm{Al}^{3+}$ may be attributed to the nickel oxides, which were dissolved as $\left[\mathrm{NiCl}_{6}\right]^{4-}$ ions, ${ }^{26}$ and the weak broad cathodic peaks at around 0.5 and $0.2 \mathrm{~V}$ vs. $\mathrm{Al} / \mathrm{Al}^{3+}$ are arrtibuted to Ni plating and under potential deposition of $\mathrm{Al}^{23,26}$

A new anodic peak appeared at around $1.0 \mathrm{~V}$ vs. $\mathrm{Al} / \mathrm{Al}^{3+}$ in the second and third sweeps. We performed the following tests to reference the peak. We began cyclic voltammetry for the same cell system

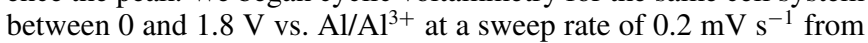
the cathodic direction at $40^{\circ} \mathrm{C}$ and stopped the second anodic sweep 

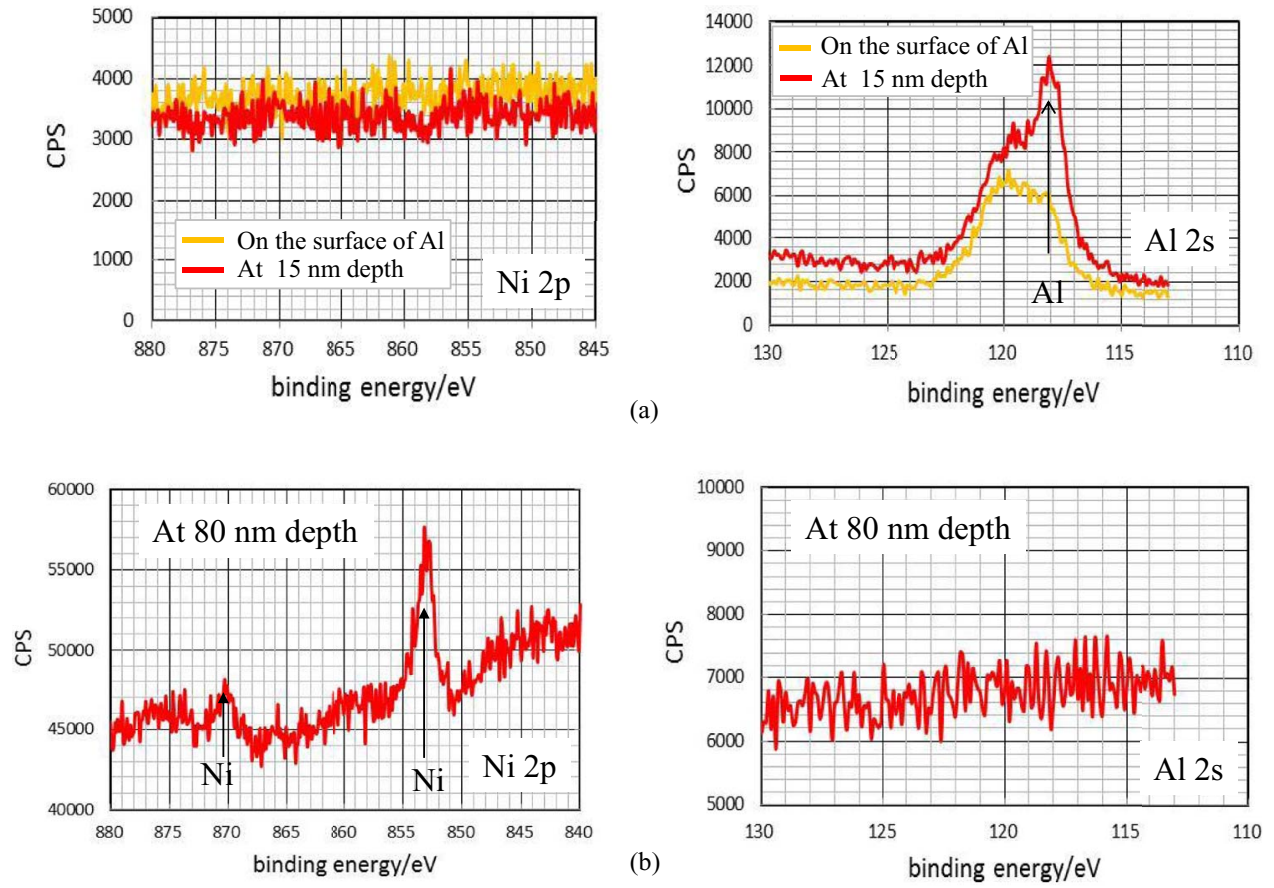

Figure 3. Ni2p and Al2s XPS spectra of Al plate for the cell having Ni composite as positive, Al plate as negative electrode after standing for $16 \mathrm{hr}$ at $40^{\circ} \mathrm{C}$. (a) In $\mathrm{AlCl}_{3} / \mathrm{BPC}$ salt with molar ratio of 0.8/1.0. (b) In $\mathrm{AlCl}_{3} / \mathrm{BPC}$ salt with molar ratio of 1.5/1.0.

at $0.95 \mathrm{~V}$ vs. $\mathrm{Al} / \mathrm{Al}^{3+}$, followed by oxidation of the $\mathrm{Ni}$ electrode at a constant voltage of $0.95 \mathrm{~V}$ vs. Al/Al ${ }^{3+}$ for 12 hours. We then washed the electrode with acetonitrile and dried it for XPS measurement. Figure 5 shows Ni2p XPS spectra for the surface and two different depths of the $\mathrm{Ni}$ electrode. Peaks attributed to $\mathrm{NiCl}_{2}$ are observed at all depths. On the other hand, peaks attributed to $\mathrm{Ni}$ metal appeared by etching. This shows that $10 \mathrm{~nm}$ or thicker $\mathrm{NiCl}_{2}$ layers formed on the Ni electrode: the anodic peak at $0.95 \mathrm{~V}$ vs. $\mathrm{Al} / \mathrm{Al}^{3+}$ in the second and third sweeps of $\mathrm{CV}$ is attributed to the oxidation of $\mathrm{Ni}$ into $\mathrm{NiCl}_{2}$.

We then performed the cyclic voltammetry for more acidic 1.1/1.0 molar ratio salts. The rest potential was $0.88 \mathrm{~V}$ vs $\mathrm{Al} / \mathrm{Al}^{3+}$ and the $\mathrm{CV}$ was started to scan in the cathodic direction. In this case, the anodic current increased significantly (Fig. 6). Ni2p XPS spectra for the Ni electrode after three sweeps of cyclic voltammetry and after 12 hours of oxidation at a constant voltage of $1.0 \mathrm{~V}$ vs. $\mathrm{Al} / \mathrm{Al}^{3+}$ are shown in Figs. 7 and 8, respectively. Both of Figs. 7 and 8 indicated the formation of nickel chloride on the electrode certainly. SEM photos of the surface of Ni electrodes before and after one and three sweeps of cyclic voltammetry are shown in Fig. 9. We observed that particulate

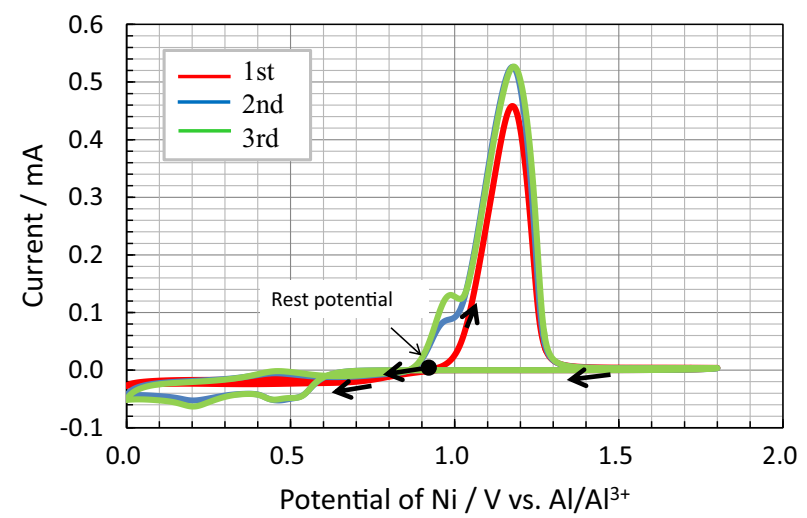

Figure 4. Cyclic voltammograms of $\mathrm{Ni}$ plate for the cell having $\mathrm{Al}$ coil as counter and reference electrodes and the $\mathrm{AlCl}_{3} / \mathrm{BPC}$ molten salt with molar ratio of $1.05 / 1.0$ at $40^{\circ} \mathrm{C}$. Scan rate was $1 \mathrm{mV} \mathrm{s}^{-1}$.

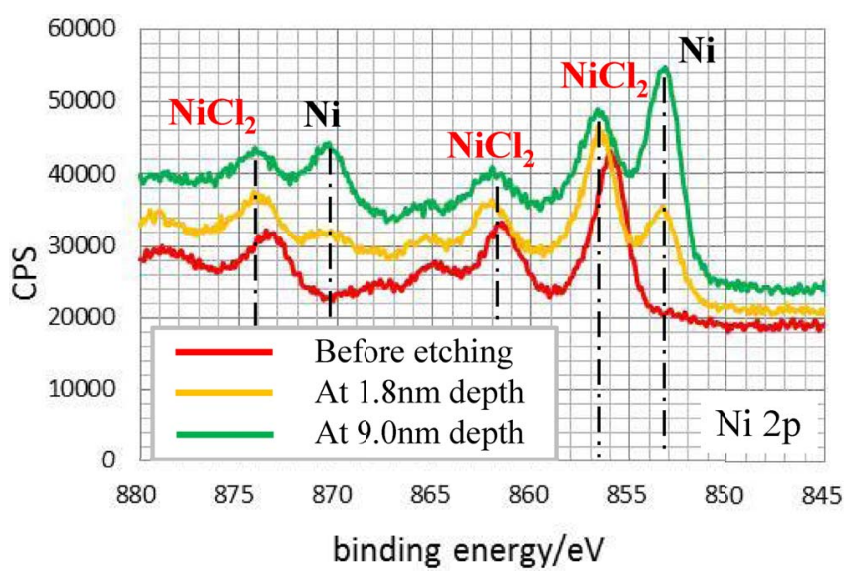

Figure 5. Ni2p XPS spectra of Ni plate after stopping cyclic voltammetry at the second anodic sweep at $0.95 \mathrm{~V} \mathrm{vs}$. $\mathrm{Al} / \mathrm{Al}^{3+}$ at $40^{\circ} \mathrm{C}$, followed by keeping the voltage for $12 \mathrm{hr}$ for the cell having $\mathrm{Al}$ coil as counter and reference electrodes and the $\mathrm{AlCl}_{3} / \mathrm{BPC}$ molten salt with molar ratio of 1.05/1.0.

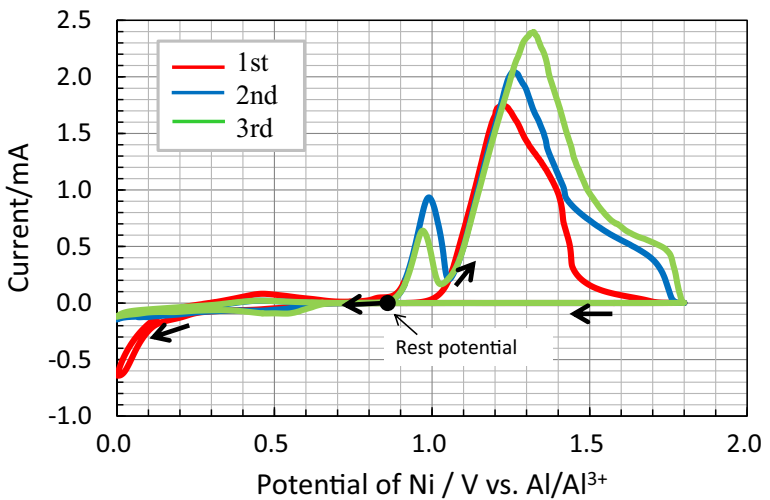

Figure 6. Cyclic voltammograms of Ni plate for the cell having $\mathrm{Al}$ as counter and reference electrodes and the $\mathrm{AlCl}_{3} / \mathrm{BPC}$ molten salt with molar ratio of $1.1 / 1.0$ at $40^{\circ} \mathrm{C}$. Scan rate was $0.2 \mathrm{mV} \mathrm{s}^{-1}$. 


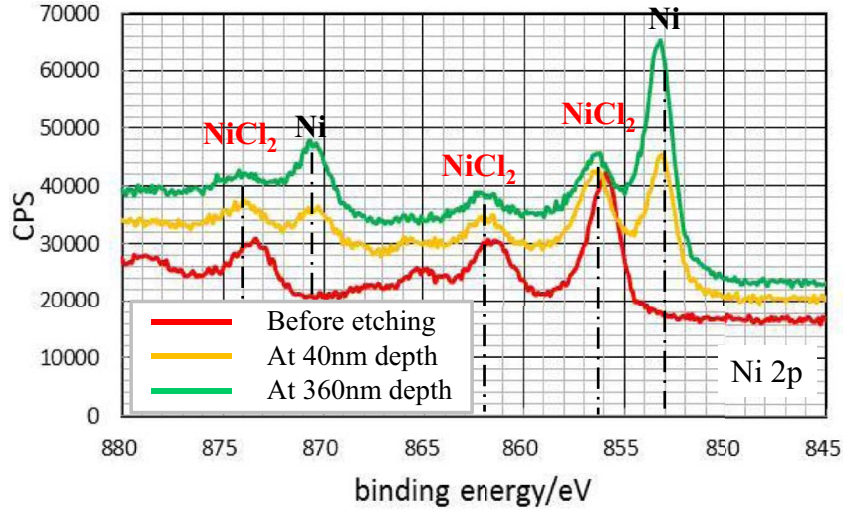

Figure 7. Ni2p XPS spectra of Ni plate after the third sweep of cyclic voltammetry at $40^{\circ} \mathrm{C}$, for the cell having $\mathrm{Al}$ coil as counter and reference electrodes and the $\mathrm{AlCl}_{3} / \mathrm{BPC}$ molten salt with molar ratio of 1.1/1.0.

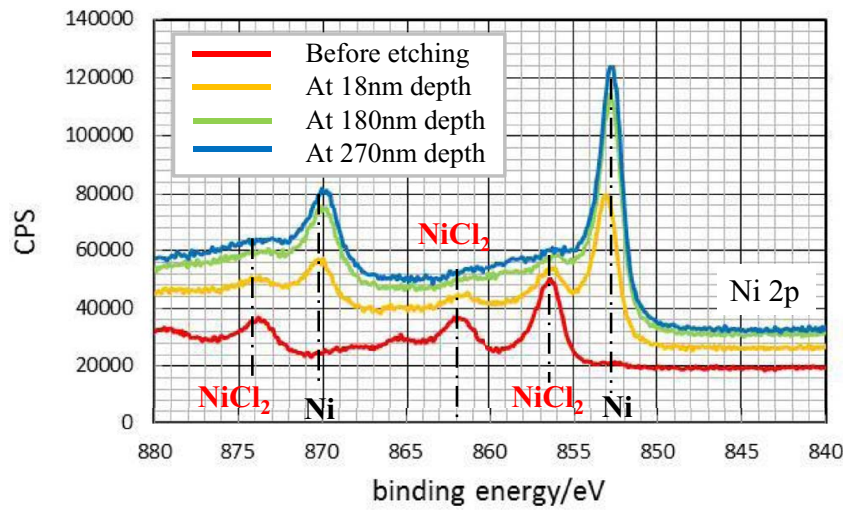

Figure 8. Ni2p XPS spectra of Ni plate after stopping cyclic voltammetry at the second anodic sweep at $1.0 \mathrm{~V}$ vs. $\mathrm{Al} / \mathrm{Al}^{3+}$ at $40^{\circ} \mathrm{C}$, followed by keeping the voltage for $12 \mathrm{hr}$ for the cell having $\mathrm{Al}$ coil as counter and reference electrodes and the $\mathrm{AlCl}_{3} / \mathrm{BPC}$ molten salt with molar ratio of 1.1/1.0.

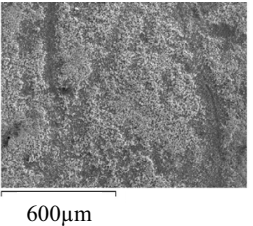

$600 \mu \mathrm{m}$

SEM photo

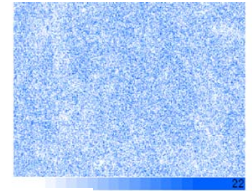

$\mathrm{Cl} \mathrm{Ka1}$

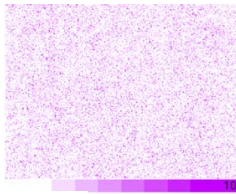

Ni Ka1
Chlorine

Nickel

Figure 10. Element mapping of EDX analysis for the Ni plate electrode in $\mathrm{AlCl}_{3} / \mathrm{BPC}$ salt with the molar ratio of $1.05 / 1.0$ after the third sweep of the cyclic voltammetry.

$\mathrm{NiCl}_{2}$ had formed on the electrode after the third sweep of cyclic voltammetry. As for the reason why the peak at $1.0 \mathrm{~V} \mathrm{vs.} \mathrm{Al} / \mathrm{Al}^{3+}$ in the first anodic sweep did not appear (Fig. 6), it was supposed that the surface area of the Ni plate electrode was not large enough to produce $\mathrm{NiCl}_{2}$ on the electrode. The peak appeared and became large because the Ni plate roughened through repeating sweep. In fact, it was observed that the first anodic sweep changed the surface state of $\mathrm{Ni}$ plate electrode as Ni dissolved to nickel ions as shown in Figs. 9a and $9 \mathrm{~b}$. Figure 10 illustrates typical results of EDX analysis for the deposited layer on the $\mathrm{Ni}$ electrode surface after the third sweep of cyclic voltammetry for the $1.05 / 1.0$ molar ratio salt. The results show $\mathrm{Ni}$ and $\mathrm{Cl}$ exist uniformly on the $\mathrm{Ni}$ electrode surface, which suggests that nickel oxidized to produce $\mathrm{NiCl}_{2}$ on the electrode.

We then demonstrated the formation of $\mathrm{NiCl}_{2}$ by oxidation of $\mathrm{Ni}$ in acidic $\mathrm{AlCl}_{3} / \mathrm{BPC}$ with molar ratios of 1.05/1.0 and 1.1/1.0 through XPS measurements. XPS measurement is effective for analyzing $\mathrm{NiCl}_{2}$ as an oxidation product of $\mathrm{Ni}$, but etching with $\mathrm{Ar}$ gas occasionally reduces the metal chlorides (for example $\mathrm{FeCl}_{2}, \mathrm{MnCl}_{2}$ ), and the energy peaks of the metal chloride are close to those of the corresponding metal, which interferes identification of the reaction products. We thus also tried to identify the $\mathrm{NiCl}_{2}$ using XRD as a measurement that can avoid such defects.

We performed cyclic voltammetry for a cell containing $0.1 \mathrm{~mm}$ thick, $12 \mathrm{~mm}$-wide and $15 \mathrm{~mm}$-long Ni plate as a working electrode, $\mathrm{Al}$ coil as a counter and a reference and $\mathrm{AlCl}_{3} / \mathrm{BPC}$ electrolyte with

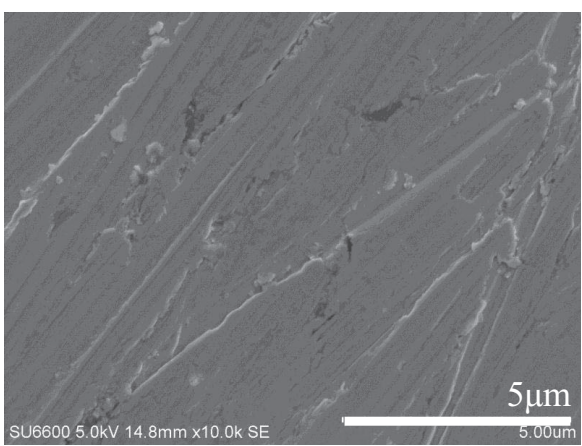

(a)

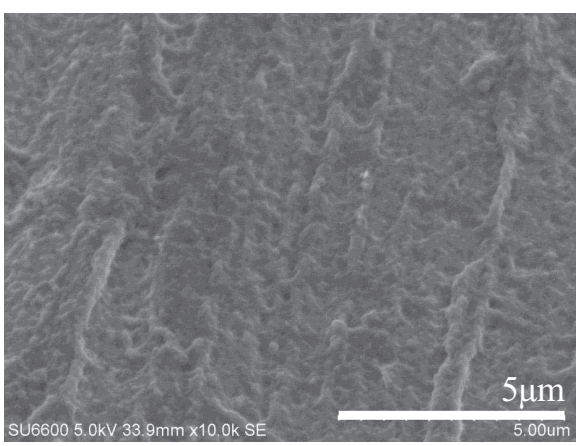

(b)

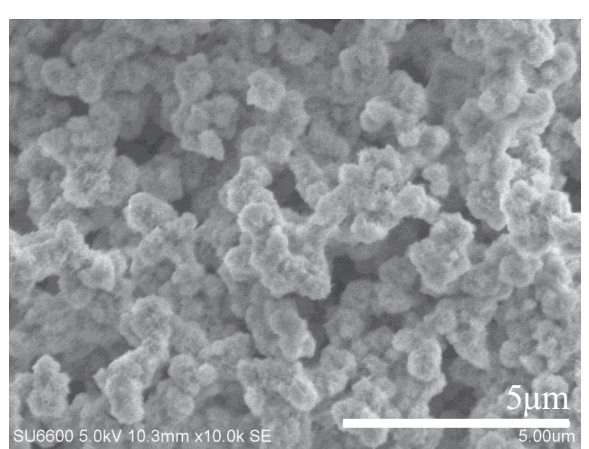

(c)
Figure 9. SEM photos of the surface of Ni plate electrode for the cell having $\mathrm{Al}$ coil as counter and reference electrodes and the $\mathrm{AlCl}_{3} / \mathrm{BPC}$ molten salt with molar ratio of 1.1/1.0. (a) Before CV. (b) After the first sweep of CV. (c) After the third sweep of CV. 


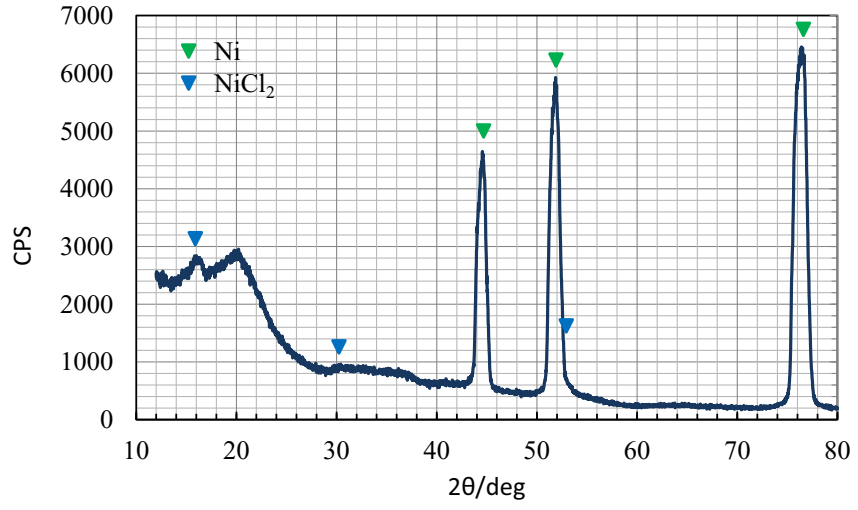

Figure 11. XRD pattern of Ni plate ( $12 \mathrm{~mm}$ wide, $15 \mathrm{~mm}$ long) electrode after stopping cyclic voltammetry at the second anodic sweep at $1.0 \mathrm{~V} \mathrm{vs.} \mathrm{Al/Al^{3+ }}$ at $40^{\circ} \mathrm{C}$, followed by keeping the voltage for $24 \mathrm{hr}$ for the cell having $\mathrm{Al}$ coil as counter and reference electrodes and $\mathrm{AlCl}_{3} / \mathrm{BPC}$ salt with molar ratio of $1.1 / 1.0$.

a molar ratio of 1.1/1.0 once, starting in the cathodic direction, and stopped the second anodic sweep at $1.0 \mathrm{~V}$ vs. $\mathrm{Al} / \mathrm{Al}^{3+}$ at $40^{\circ} \mathrm{C}$, followed by 24 hours of oxidation at a constant voltage of $1.0 \mathrm{~V}$ vs. $\mathrm{Al} / \mathrm{Al}^{3+}$ to produce $\mathrm{NiCl}_{2}$ on the electrode. We then measured the $\mathrm{NiCl}_{2}$ film formed on the surface of the $\mathrm{Ni}$ electrode by low-incidence XRD (the incidence angle was fixed at $3^{\circ}$ and the instrument was operated in a step-scan mode in increments of $0.02^{\circ}$ with counts accumulated for $1.5 \mathrm{~s}$ at each step). The XRD pattern of the Ni electrode is shown in Fig. 11. The data indicate the existence of a thin $\mathrm{NiCl}_{2}$ film on the Ni surface.

We estimated the electrochemical properties of the Ni electrode in more acidic $\mathrm{AlCl}_{3} / \mathrm{BPC}$ salt with a molar ratio of 1.5/1.0. We further performed cyclic voltammetry at a scan rate of $0.2 \mathrm{mV} \mathrm{s}^{-1}$ at $40^{\circ} \mathrm{C}$, and 12 hours oxidation at $1.0 \mathrm{~V}$ vs. $\mathrm{Al} / \mathrm{Al}^{3+}$ after stopping the second anodic scan of the $\mathrm{CV}$ at $1.0 \mathrm{~V}$ vs. $\mathrm{Al} / \mathrm{Al}^{3+}$. The results are shown in Figs. 12 and 13. The rest potential was $0.87 \mathrm{~V}$ vs Al/ $\mathrm{Al}^{3+}$ and the $\mathrm{CV}$ was started to scan in the cathodic direction. An anodic peak at around $1.0 \mathrm{~V}$ vs. $\mathrm{Al} / \mathrm{Al}^{3+}$ appeared in the second and third sweeps. This indicates $\mathrm{NiCl}_{2}$ formation on the surface of $\mathrm{Ni}$, and the feature is the same as that for other acidic salts. However, the Ni2p XPS spectra suggested less $\mathrm{NiCl}_{2}$ formation than for other acidic salts.

Regarding our results, $\mathrm{NiCl}_{2}$ formation by oxidation of $\mathrm{Ni}$ occurs under conditions of limited acidity in $\mathrm{AlCl}_{3} / \mathrm{BPC}$. Nickel is oxidized into $\left[\mathrm{NiCl}_{4}\right]^{2-}$ in basic and neutral $\mathrm{AlCl}_{3} / \mathrm{BPC}$ salts where the majority of $\mathrm{Cl}^{-}$ions exist. In the $\mathrm{AlCl}_{3} / \mathrm{BPC}$ with molar ratios of $1.05 / 1.0$ and 1.1/1.0 where limited $\mathrm{Cl}^{-}$ions exist, it appears that the nickel is oxidized to nickel chloride with chloride ions formed through reduction

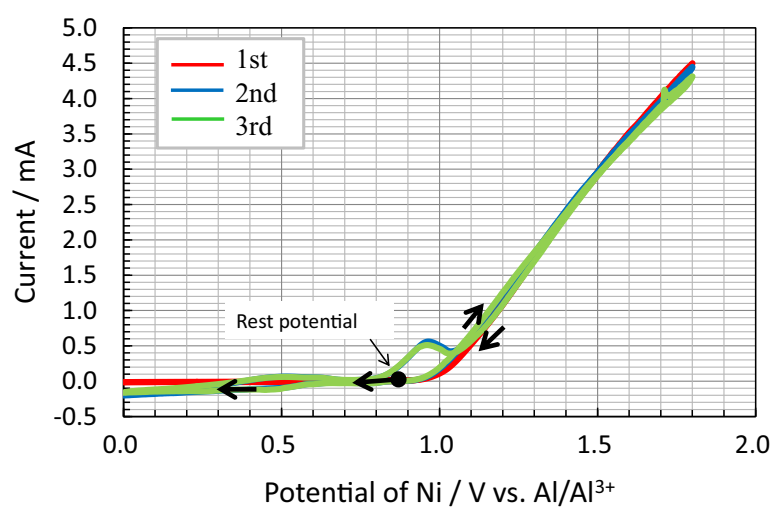

Figure 12. Cyclic voltammograms of Ni plate for the cell having $\mathrm{Al}$ coil as counter and reference electrodes and the $\mathrm{AlCl}_{3} / \mathrm{BPC}$ molten salt with molar ratio of $1.5 / 1.0$ at $40^{\circ} \mathrm{C}$. Scan rate was $0.2 \mathrm{mV} \mathrm{s}^{-1}$.

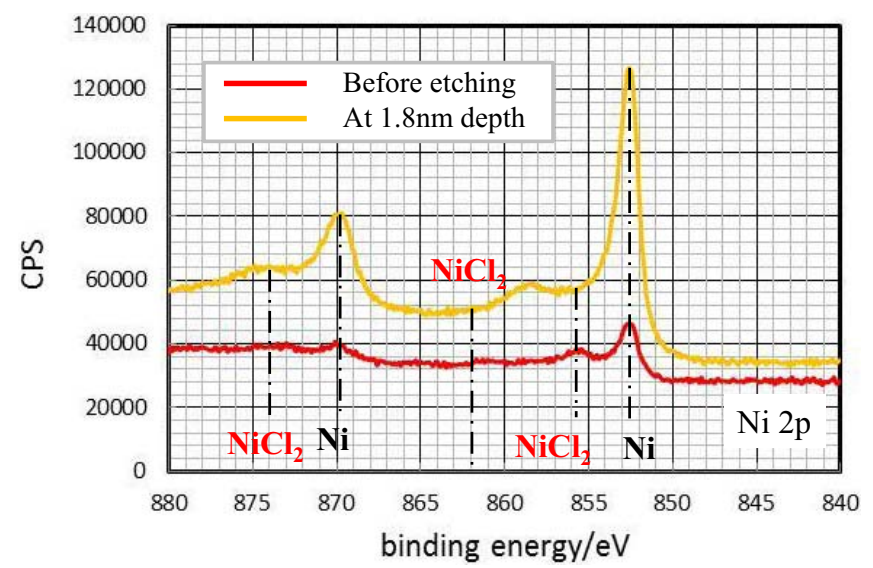

Figure 13. Ni2p XPS spectra of Ni plate after stopping cyclic voltammetry at the second anodic sweep at $1.0 \mathrm{~V}$ vs. $\mathrm{Al} / \mathrm{Al}^{3+}$ at $40^{\circ} \mathrm{C}$, followed by keeping the voltage for $12 \mathrm{hr}$ for the cell having $\mathrm{Al}$ coil as counter and reference electrodes and the $\mathrm{AlCl}_{3} / \mathrm{BPC}$ molten salt with molar ratio of 1.5/1.0.

of the $\left[\mathrm{AlCl}_{4}\right]^{-}$or $\left[\mathrm{Al}_{2} \mathrm{Cl}_{7}\right]^{-}$ions at the negative electrode, ${ }^{18}$ because the slightly acidic conditions mainly contain $\left[\mathrm{AlCl}_{4}\right]^{-}$and $\left[\mathrm{Al}_{2} \mathrm{Cl}_{7}\right]^{-}$ ions. . $^{15}$

This $\mathrm{NiCl}_{2}$ formation, however, decreased in more acidic $\mathrm{AlCl}_{3} / \mathrm{BPC}$ with the $\mathrm{AlCl}_{3}$ ratio larger than 1.1. It is considered that $\mathrm{Ni}$ is dissolved to form $\left[\mathrm{Ni}\left(\mathrm{Al}_{2} \mathrm{Cl}_{7}\right)_{3}\right]^{-}$and $\left[\mathrm{Ni}\left(\mathrm{Al}_{2} \mathrm{Cl}_{7}\right)_{4}\right]^{2-}$ ions, ${ }^{26}$ because $\left[\mathrm{Al}_{2} \mathrm{Cl}_{7}\right]^{-}$ions may exist predominantly in the strong acidic conditions at a molar ratio of $1.5 / 1.0 .{ }^{15}$ We therefore observed the linear increased in anodic current with shifted potential positively from $1.0 \mathrm{~V}$ vs. $\mathrm{Al} / \mathrm{Al}^{3+}$ only in the $1.5 / 1.0$ molar ratio salt (Fig. 12). Further study is also needed to clarify the reaction mechanism.

\section{Summary}

We studied the electrochemical properties of nickel in molten salt containing $\mathrm{AlCl}_{3}$ and 1-butylpyridinium chloride (BPC) at $40^{\circ} \mathrm{C}$. We mainly performed cyclic voltammetry to investigate the reaction and XPS and XRD to identify the reaction products. The results we obtained are summarized as follows:

(1) Solubility of the reaction product into the electrolyte critically affects the efficiency of the electrochemical reaction. Our approximation of $\mathrm{NiCl}_{2}$ solubility showed a 15 -fold difference between $\mathrm{AlCl}_{3} / \mathrm{BPC}$ molar ratios of 1.5/1.0 and 0.9/1.0.

(2) Regarding the results of cyclic voltammetry of nickel, nickel was oxidized to produce $\mathrm{NiCl}_{2}$ in slightly acidic $\mathrm{AlCl}_{3} / \mathrm{BPC}$ salts with molar ratios of $1.05 / 1.0$ and $1.1 / 1$.0. The $\mathrm{NiCl}_{2}$ produced in the acidic salt with a ratio of $1.5 / 1.0$ was less than that produced in the slightly acidic $1.05 / 1.0$ and $1.1 / 1.0$ salts because of differences in the ionic species in the salt.

(3) XPS data suggested that no $\mathrm{NiCl}_{2}$ was produced on the electrode in basic and neutral salts. In the salts, the electrolyte turned blue, which suggests that nickel was oxidized into $\left[\mathrm{NiCl}_{4}\right]^{2-}$ ions.

\section{Acknowledgment}

This work was financially supported by the New Energy and Industrial Technology Department Organization (NEDO) Japan.

\section{References}

1. J. M. Tarascon and M. Armand, Nature, 414, 359 (2001).

2. J. Wang and X. Sun, Energy Environ. Sci., 5, 5163 (2012).

3. K. M. Abraham and Z. Jiang, J. Electrochem. Soc., 143, 1 (1996).

4. Y. X. Yin, S. Xin, Y. G. Guo, and L. J. Wan, Angewandte Chemie-International Ed., 52, 13186 (2013)

5. B. Liu, T. Luo, G. Mu, X. Wang, D. Chen, and G. Shen, ACS Nano, 7, 8051 (2013).

6. M. A. Reddy and M. Fichtner, J. Mater. Chem., 21, 17059 (2011). 
7. B. L. Ellis and L. F. Nazar, Current Opinions in Solid State \& Mater. Sci., 16, 168 (2012).

8. H. Zhou, Y. Wang, H. Li, and P. He, ChemSusChem, 3, 1009 (2010).

9. H. Lewis, W. Hwang, and M. Manzo, J. Power Sources, 136, 307 (2004).

10. Y. Ito, M. Nyce, R. Plivelich, M. Klein, and S. Banerjee, J. Power Sources, 196, 6583 (2011).

11. V. A. Kozyrin and V. N. Flerov, Russian J. Appl. Chem., 86, 20 (2013).

12. B. C. Knutz, H. A. Hjuler, R. W. Berg, and N. J. Bjerrum, J. Electrochem. Soc., 140 3374 (1993).

13. B. C. Knutz, H. A. Hjuler, R. W. Berg, and N. J. Bjerrum, J. Electrochem. Soc., 140, 3380 (1993).

14. B. Gilbert and R. A. Osteryoung, J. Amer. Chem. Soc., 100, 2725 (1978).

15. R. J. Gale and R. A. Osteryoung, Inorg. Chem. 18, 1603(1979).

16. R. J. Gale, B. Gilbert, and R. A. Osteryoung, Inorg. Chem. 18, 2723 (1979).

17. N. Koura, T. Yui, and S. Takahashi, KEIKINZOKU, 35, 203 (1985), in Japanese.

18. S. Takahashi, N. Koura, and R. Nakajima, DENKIKAGAKU, 54, 257 (1986), in Japanese.

19. N. Takami and N. Koura, J. Electrochem. Soc., 140, 928 (1993).
20. N. Koura, H. Ejiri, and K. Takeishi, J. Electrochem. Soc., 140, 602 (1993).

21. R. I. Crisp, C. L. Hussey, and K. R. Seddon, Polyhedron, 14, 2819 (1995).

22. F. M. Donahue, S. E. Mancini, and L. Simonsen, J. Appl. Electrochem., 22, 230 (1992).

23. D. F. Roeper, G. T. Cheek, K. I. Pandya, and W. E. O'Grady, ECS Trans., 11, 29 (2008).

24. D. F. Roeper, K. I. Pandya, G. T. Cheek, and W. E. O'Grady, J. Electrochem. Soc., 158, F21 (2011).

25. W. E. O'Grady, D. F. Roeper, K. I. Pandya, and G. T. Cheek, Power Diffraction, 26, 171 (2011).

26. J. F. Parker, G. T. Cheek, D. F. Roeper, and W. E. O'Grady, ECS Trans., 41, 23 (2012).

27. S. Pye, J. Winnick, and P. A. Kohl, J. Electrochem. Soc., 144, 1933 (1997).

28. W. R. Pitner and Charles L Hussey, J. Electrochem. Soc., 143, 130 (1996).

29. R. T. Carlin and H. C. De Long, J. Fuller and P. C. Trulove, J. Electrochem. Soc., 145, 1598(1998).

30. C.-X. Zu and H. Li, Supplementary material (ESI) for Energy \& Environ. Sci. (2011). 